\title{
Integration of 21st Century Learning Skills (4C Elements) in Interventions to Improve English Writing Skill Among 3K Class Students
}

\author{
Tan Xin $\mathrm{Yu}^{1}$, Wan Muna Ruzanna Wan Mohammad ${ }^{1}$ \\ ${ }^{1}$ Faculty of Education, National University of Malaysia, Bangi, Malaysia \\ Correspondence: Tan Xin Yu, Faculty of Education, National University of Malaysia, Bangi, Malaysia. \\ E-mail: zincyu915@gmail.com
}

Received: August 29, 2019

Accepted: September 8, 2019 Online Published: September 9, 2019

doi:10.11114/ijce.v2i2.4498

URL: https://doi.org/10.11114/ijce.v2i2.4498

\begin{abstract}
21st Century Learning is a student-centered learning process that has been introduced in Malaysia since 2014. This study aims to integrate the $4 \mathrm{C}$ elements, which are collaboration, communication, creativity, and critical thinking in the interventions to improve English writing skill among $3 \mathrm{~K}$ class students. Also, the study was conducted to determine how peer guidance can help $3 \mathrm{~K}$ class students, who were weak in writing, to improve their English writing skills. The action research was carried out based on Kurt Lewin's Model. The research instruments involved were pre-test, post-test, and semi-structured interview. A total of 32 students sat for both pre-test and post-test before and after the interventions. A semi-structured interview consisting of five questions was conducted after the student completed the post-test. Descriptive statistics involving mean and percentage scores were used to analyze pre-test and post-test findings, while the interview findings were summarized. The results showed that there was an improvement in their English writing skills, where the mean score for the pre-test was 19.34, while the mean score for post-test was 22.66. The findings indicate that weaker students agreed that guidance of students who possess better writing skills helped them improve their English writing skills. The results of the pre-test and post-test showed that the intervention conducted has successfully helped $3 \mathrm{~K}$ class students to improve their English writing skills.
\end{abstract}

Keywords: 4C elements, intervention, peer guidance, English writing skill

\section{Introduction}

\subsection{Background and Problem Statement}

English is a language that should be mastered by individuals for lifelong learning as the mastery of the language gives students an opportunity to explore multiple fields of knowledge (Shaik Riyaz Ahmad 2016). However, Malaysian students are less likely to master English writing skills as English is not the native language for most of the students. The research findings of Ghabool, Mariadass, and Kashef (2012) showed that most students have difficulty with grammar and punctuation in writing because they were influenced by the grammar system used in their native language. This researcher identified that the main problem was that students were not able to generate writing ideas competently and have failed to use the right capitalization, spelling, grammar, and punctuation in writing exercises.

The research findings of Azizah Abu Hanifah's (2009) showed that English proficiency among students was much lower than their speaking and listening skills. In addition, the findings of Maros, Tan and Khazriyati Salehuddin (2007) also showed that there were many grammatical errors in English essay writing exercises, even though students had learned the proper usage of capitalization, spelling, grammar, and punctuation for six years in primary school. The teaching strategies, methods, and techniques that were chosen by English teachers to conduct their writing lessons were more traditional, which indirectly limited their pupils' learning and made them less likely to engage in teaching and learning activities (Lourenco \& Jones 2006). Besides, a study conducted by Lim (2013) suggested that the teaching process of reading, listening, or writing skills should not be solely dependent on repetition.

Therefore, this study aims to improve $3 \mathrm{~K}$ class students' ability to write simple English sentences through two sets of 4 C's-based interventions. In the first set of intervention, students listed keywords that were related to the title given, which was "My Family" in a group consisting of two students who possessed better writing skill and two weaker students. In the second set of intervention, students produced four simple sentences based on the keywords listed in the first set of intervention. Clearly, the $4 \mathrm{C}$ elements that were adopted in the interventions created communication and 
collaboration opportunities between students who possessed better writing skills and the weaker students, leading to an increase in their mastery of the capitalization, spelling, grammar, and punctuation in writing. Additionally, the creativity and critical thinking elements that were incorporated into the interventions also helped students to develop writing ideas.

In general, the study was carried out based on two objectives: (i) Integrating the $4 \mathrm{C}$ skills in the interventions to improve English writing skill among $3 \mathrm{~K}$ class students and (ii) Identify the effectiveness of peer guidance in helping $3 \mathrm{~K}$ class students who were weak in writing to improve their English writing skills. The study was carried out based on Kurt Lewin's model, which the process starts from planning solutions, taking action, observing, and finally reflecting (Larson 2006). As a result, the study provided examples for English language teachers to plan student-centered teaching and learning activities based on the $4 \mathrm{C}$ elements to enhance writing skills among students.

\subsection{Importance of the Problem}

A few issues relating to poor writing skills were identified by this researcher during the process of teaching English writing techniques in $3 \mathrm{~K}$ class. When students were given an essay title, it was observed that most students could not begin to write on their own because they had no idea how to start writing. In addition, the sentences constructed by the students contained many errors in capitalization, grammar, spelling, and punctuation. By recognizing the problems inherent in $3 \mathrm{~K}$ class students, this researcher decided to integrate $4 \mathrm{C}$ elements, which are collaboration, communication, creativity and critical thinking, in the teaching of English writing to enable students to master the fundamental aspects in English writing, which include capitalization, grammar, spelling, and punctuation.

Generally, the English language is widely regarded as an international language. It has been an important subject in the Malaysian education system since independence, where the Malaysian Ministry of Education (MoE) launched programs, such as the Dual Language Program (DLP) and the High Immersive Program (HIP) recently to improve English proficiency among students by creating a learning environment that emphasized the importance of English in schools. Additionally, high school students who wish to further their studies in universities are required to sit for the "Malaysian University English Test" or more commonly known as MUET. The purpose of the examination is to assess the level of English proficiency of students who are pursuing a bachelor's degree (Rethinasamy \& Chuah 2011). In conclusion, if students failed to master the basic aspects in writing, which include capitalization, grammar, spelling, and punctuation, they will not be able to succeed or master any field of knowledge completely in their further studies. Thus, this study is important to improve $3 \mathrm{~K}$ class students English writing skills, and the findings can help teachers in improving their teaching.

\subsection{Literature Review}

21 st-century learning is commonly defined as an education reform that aims to equip every student with the essential skills to face 21st-century challenges (Beetham \& Sharpe 2013). 21st-century learning was introduced in Malaysia in 2014. It emphasized four key elements, which are communication, collaboration, creativity, and critical thinking, also known as the 4 C's (Aminuddin Baki Institution 2017). However, a portion of teachers have yet to understand this concept in-depth and chose to continue teaching using traditional techniques that do not benefit the students. Thus, this researcher took the incentive to integrate elements of the $4 \mathrm{C}$ 's, that are present in 21 st-century teaching, in interventions to increase students' interest in English writing.

Sala dan Redford (2012) stated in their study that writing is a skill that closely relates to one's self-belief to produce quality writing. In this context, students can increase their confidence through writing by making use of the four key elements, which are collaboration, communication, creativity, and critical thinking. This is because students can enhance their skill of writing simple sentence through interventions, which will lead to increased confidence to write in English and form paragraphs.

According to Elola and Oskoz (2010), integrating the element of collaboration during learning activities enables students to develop their ideas more effectively compared to studying alone. Here, students were given the opportunity to exchange views and opinions with their friends, and through this exchange of ideas, students can gain inspirations to be included in their writing. Additionally, collaboration also enables students in a group to evaluate their accuracy in capitalization, spelling, grammar, and punctuation in the sentences they constructed.

Communication with their peers helps weaker students to improve their writing skills through discussions with students who are more competent because they are more comfortable with their friends, whereas some students may feel shy or embarrassed to ask for help from their teachers during classes (Jones 2007). For example, weaker students have the chance to improve their capitalization, spelling, grammar, and punctuation under the guidance of their more accomplished peers. Furthermore, the skill levels of each weak student differ significantly. For example, Student A may be weak in using present continuous tense, while Student B has a weaker grasp of past tense. Therefore, guidance from 
their peers in various groups can help weaker students master specific skills in stages.

According to a study by Lin (2011), adopting the creative element during teaching and learning should be performed in stages to guide the students to think creatively. In this context, students developed their writing ideas alone, in the second set of intervention, based on keywords listed during the first set of intervention. During the second set of intervention, skilled students within each group raised questions to guide weaker students to relate their personal experience to the writing topic.

Nauman, Stirling, and Borthwick (2011) stated that critical thinking is crucial in writing, where students can obtain quality writing ideas through critical thinking. Here, the more accomplished students posed questions and postulated likely outcomes based on the topic to stimulate other members of the group. This way, students within a group can exchange opinions to produce a variety of writing.

In their study, Shabani, Khatib dan Ebadi (2010) found that students that participated in intervention exercises based on Vygotsky's Zone of Proximal Development theory were able to produce more challenging works with the help of their more accomplished peers. Hence, the researcher assigned two students who possess better writing skill with two weak students in a group during the interventions, so that the more competent students can guide the weaker students to generate writing ideas and master the correct usage of capitalization, spelling, grammar, and punctuation.

According to Harland (2003), children who were weaker at specific skills were able to complete a more complex activity with guidance from an adult or their more accomplished peers. Thus, this researcher identified the more competent and weaker students before this study to facilitate group assignment. With the help of more accomplished students during the planned interventions, weaker students can master the usage of capitalization, grammar, spelling, and punctuation. They managed to list out keywords that were related to the given topic.

In a study by Levykh (2008), weaker students that were mentored by the more competent students successfully completed activities that were considered to have exceeded their abilities and boosted the weaker students' self-confidence. Furthermore, the weaker students were more motivated to participate in subsequent teaching and learning activities. This researcher, being aware of the importance of peer mentoring, planned an intervention based on collaboration and communication to enable students who are more competent in the usage of capitalization, grammar, spelling, and punctuation to guide their weaker peers.

Apart from that, the interventions were also planned based on Paulo Freire's Theory of Education, that stressed on the process of an individual's active and critical thinking in the formation of ideas and opinions based on the topic of learning. In this context, students built on their prior knowledge by relating previous learning experiences with their current learning (Roberts 2009). Hence, the weaker students can form writing ideas more fluidly because the writing topic (current learning) was related to their previous knowledge.

Additionally, Robert Sternberg's Creativity Model was used as a reference during the planning of the interventions. Robert Sternberg's Creativity Model emphasized the element of creativity in the learning process, where educators should encourage students to come up with ideas. According to this model, every educator has the responsibility to raise questions that will guide students toward creative thinking during the teaching process. Here, the writing activities that were performed provided opportunities for the weaker students to develop their creative ideas through questions posed by their group members. Group discussions encouraged the exchange of ideas and opinions that helped the students to think creatively. A study by Wang (2007) found that brainstorming activities were more suitable to be performed in small groups, where students were given a chance to bring up their ideas in a controlled learning environment. Thus, weaker students can master techniques to form writing ideas in stages under the guidance of their more accomplished peers. Accordingly, interventions were planned based on the elements of $4 \mathrm{C}$, which are collaboration, communication, creativity, and critical thinking, to improve the English writing skill among the students of Class $3 \mathrm{~K}$.

\subsection{Research Questions}

As stated earlier, the two research objectives of this study were to integrate the $4 \mathrm{C}$ elements into interventions to improve English writing skill among $3 \mathrm{~K}$ class students and determine how peer guidance can help weak students improve their writing skills. Based on these objectives, the research questions of this study are as follows:

- Can the integration of 4C elements (21st-century learning) in interventions improve English writing skills among 3K class students?

- How well does peer guidance help weaker students to improve English writing skills among $3 \mathrm{~K}$ students?

\section{Method}

This section will discuss methodologies that include research participants, research setting, research design, interventions procedures and data-collecting procedures and instruments involved. In this context, the researcher 
described each section of this research in detail by using clear and simple language to enhance the reader's understanding of the study.

\subsection{Identify Subsections}

This researcher divided the methodology into several parts, which are (i) research participants, (ii) research setting, (iii) research design, (iv) interventions procedures and (v) data-collecting procedures and instruments involved to help readers find specific information.

\subsection{Research Participants}

There were 32 students from $3 \mathrm{~K}$ class, including 16 female students and 16 male students. They were selected as participants of the study by using purposive sampling technique because the characteristics of the students were in line with the focus and objectives of this study. The $3 \mathrm{~K}$ class students were chosen as the participants of this study because the mastery of English writing skills involving the usage of capitalization, grammar, spelling, and punctuation were at moderate and weak levels, with most of these students scoring either Grade B (Moderate level) or Grade C (Poor level) in English writing. The selected students did not have any certified learning disabilities. After a careful review by this researcher in a previous writing exercise completed by the $3 \mathrm{~K}$ class students, it was found that most of these students were still poor at capitalization, grammar, spelling, and punctuation. They also appeared to have difficulties on how to start writing when they were asked to write simple sentences based on a title given.

In this context, the researchers analyzed the results of last year's examination to identify students who were more proficient and those who were weak in English writing skills. The purpose of this researcher analyzing last year's examination results was to assign two students who have good writing skills and two weak students in a group to participate in interventions. As a result of this analysis, the researcher identified 16 weak students (Grade C) and 16 students who possessed better writing skill (Grade A \& B). The results of last year's (2018) examination results are as follows, where the students scored Grade A (Good), Grade B (Moderate) and Grade C (Poor) in English writing examination:

Table 1. Results of 3K class students in the English writing examination from last year (2018)

\begin{tabular}{c|c|c|c|c|c}
\hline No & Student & Grade & No & Student & Grade \\
\hline 1 & S1 & C & 17 & S17 & A \\
\hline 2 & S2 & A & 18 & S18 & C \\
\hline 3 & S3 & C & 19 & S19 & C \\
\hline 4 & S4 & A & 20 & S20 & C \\
\hline 5 & S5 & A & 21 & S21 & A \\
\hline 6 & S6 & A & 23 & S23 & C \\
\hline 7 & S7 & B & 24 & S24 & C \\
\hline 8 & S8 & B & 25 & S25 & A \\
\hline 10 & S9 & C & 26 & S26 & B \\
\hline 11 & S10 & C & 27 & S27 & C \\
\hline 12 & S12 & A & 28 & S28 & C \\
\hline 13 & S13 & C & 29 & S29 & A \\
\hline 14 & S14 & C & 30 & S30 & B \\
\hline 15 & S15 & B & 31 & S31 & A \\
\hline 16 & S16 & C & 32 & S32 & P \\
\hline
\end{tabular}

Based on last year's examination results, this researcher divided the students into eight groups to participate in the first and second set of interventions. The distribution of the groups for the $3 \mathrm{~K}$ class students is shown as follows, where students who possessed better writing skill in each group are highlighted: 
Table 2. Group distribution of $3 \mathrm{~K}$ class students during interventions

\begin{tabular}{|c|c|c|c|}
\hline Group & Student & Group & Student \\
\hline \multirow[t]{4}{*}{ Group 1} & $\mathrm{~S} 2$ & \multirow[t]{4}{*}{ Group 5} & S15 \\
\hline & $\mathrm{S} 4$ & & S17 \\
\hline & $\mathrm{S} 1$ & & S19 \\
\hline & $\mathrm{S} 3$ & & $\mathrm{~S} 20$ \\
\hline \multirow[t]{4}{*}{ Group 2} & S5 & \multirow[t]{4}{*}{ Group 6} & S22 \\
\hline & S6 & & S26 \\
\hline & S10 & & $\mathrm{S} 21$ \\
\hline & S11 & & $\mathrm{S} 23$ \\
\hline \multirow[t]{4}{*}{ Group 3} & S7 & \multirow[t]{4}{*}{ Group 7} & S27 \\
\hline & $\mathrm{S} 8$ & & $\mathrm{~S} 30$ \\
\hline & S13 & & S24 \\
\hline & S14 & & $\mathrm{S} 25$ \\
\hline \multirow[t]{4}{*}{ Group 4} & S9 & \multirow[t]{4}{*}{ Group 8} & S31 \\
\hline & $\mathrm{S} 12$ & & S32 \\
\hline & S16 & & $\mathrm{S} 28$ \\
\hline & S18 & & S29 \\
\hline
\end{tabular}

Besides that, these students showed high interest to engage in group activities, where they appeared to be more interested and excited when the researcher divided them into small groups to conduct learning activities in previous teaching and learning sessions. Therefore, it can be concluded that these students were suitable to be selected as this study's samples to participate in the group-based interventions to improve their English writing skills.

\subsection{Research Setting}

The study was conducted at a National Chinese Primary School located in the northeastern district of Penang, Malaysia with 710 students, including 370 male students, 340 female students, and 43 teachers. The school is located in the city of Georgetown, which is strategically close to various amenities such as markets, grocery stores, and government hospitals. The school was chosen for this study because it is an average-performing school, where the results of the Primary School Assessment Report (PPSR) for English writing in 2018 were moderate. Therefore, the school was well suited to conduct this research, which aims to improve the students English writing skills through the integration of $4 \mathrm{C}$ elements (collaborative, communication, creativity and critical thinking) in interventions.

\subsection{Research Design}

The study was conducted in the form of action research based on Kurt Lewin's Model, involving four steps in a cycle, which are planning, action, observation, and finally reflection:

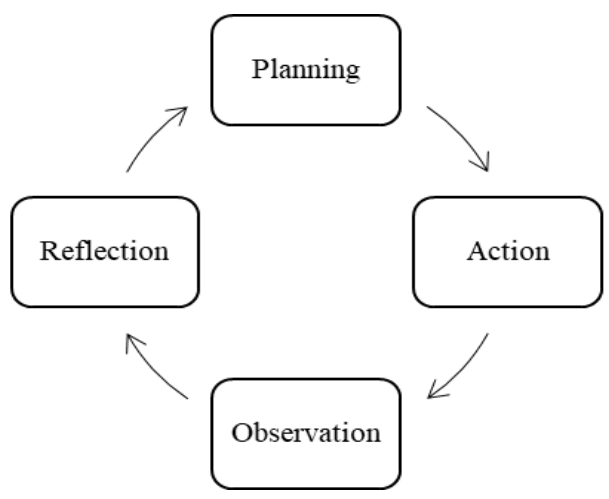

Figure 1. Kurt Lewin's Model of action research (Lewin 1946)

Based on Kurt Lewin's model, the researcher initiated the study with the first step, which is to plan solutions to address 
the issues that arise. Next, the researcher acted by implementing the planned solutions in the first step. During the process of interventions, the researcher recorded observations to collect data on the effectiveness of the interventions. After analyzing the results, the researcher reflected on the entire research process and outlined the weaknesses and strengths of the study. The researcher also suggested improvements. The process of conducting the study based on Kurt Lewin's model is summarized in Figure 2.
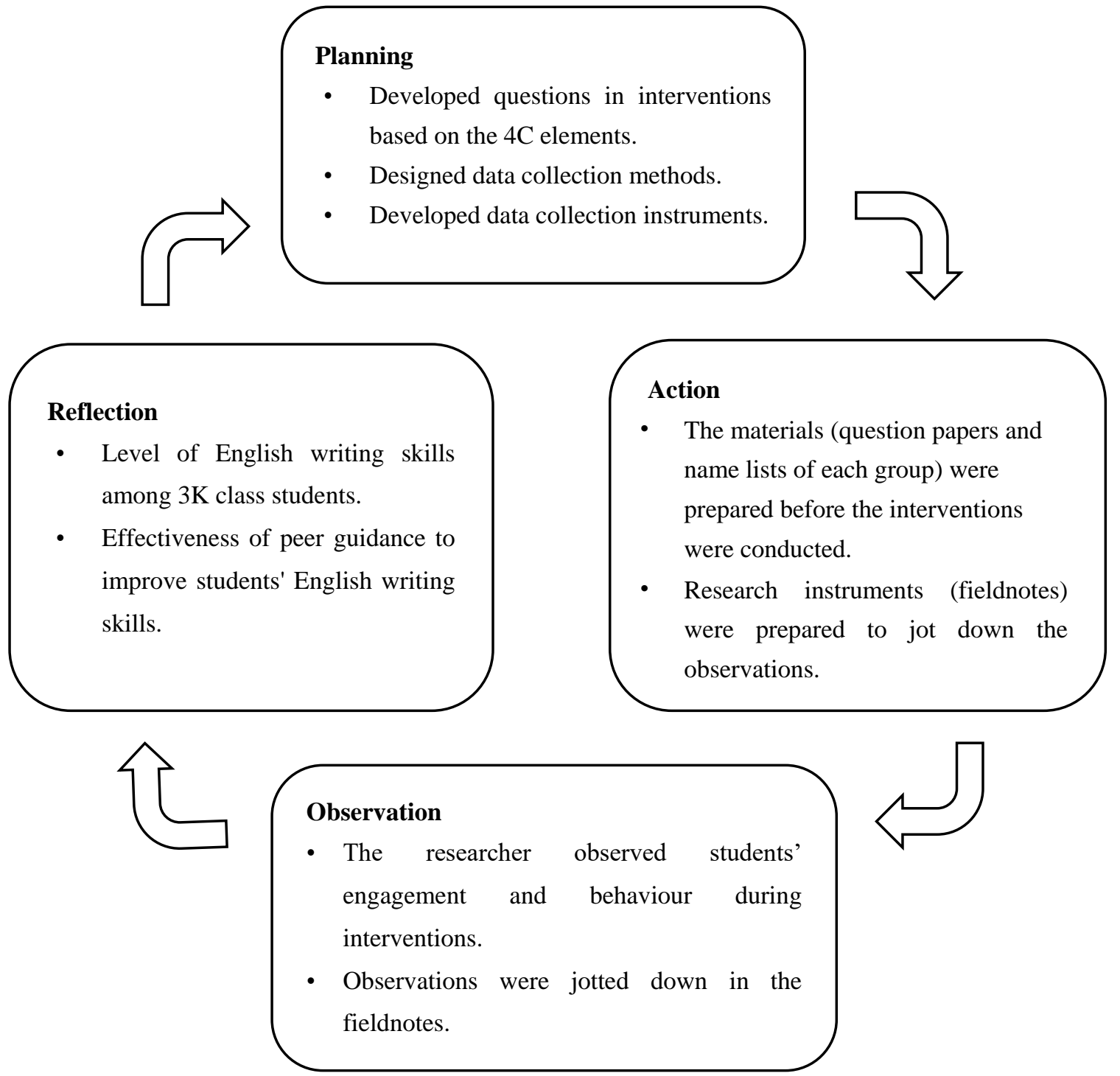

Figure 2. The action plan based on Kurt Lewin's Model of action research

Based on the action plan outlined above, the researcher developed intervention questions in the planning stage after identifying the problems faced by $3 \mathrm{~K}$ class students, where they failed to generate writing ideas smoothly and were also weak in the mastery of capitalization, grammar, spelling, and punctuation. The intervention questions were also developed based on the Malaysian Year Three English Textbook, Malaysian Year Three Standard Curriculum and Assessment Standard (DSKP) and 21st Century Learning Information Kit. During the process of developing the intervention questions, the researcher prioritized Learning Standard 4.3.3 in the English language, which the learning standard stated that students are supposed to be able to plan, produce drafts and write a variety of simple sentences. Additionally, the researcher also designed the data collection methods, including observations, semi-structured interview, pre-test, and post-test.

In the second step of the cycle, the researcher taught the keywords to be used in the interventions a week before the interventions took place. Besides that, the researcher arranged the chairs in $3 \mathrm{~K}$ class to facilitate group-based interventions. In this context, two more accomplished students would sit in a group with two weaker students. Before the interventions started, fieldnotes were prepared for the researcher to jot down the results, while the rubric (Appendix 
D) was prepared to assess the students' writing skills in pre-test and post-test (Appendix C). Once all the materials were prepared, the researcher distributed the intervention question papers (Appendix A \& B) to each group and explained the topic given to all students. Next, the students listed the keywords in the first set of intervention and wrote sentences in the second set of intervention.

For observation purposes, the researcher jotted down the observations in the fieldnotes prepared in advance and recorded the interventions with a smartphone. Next, the researcher analyzed the observations based on fieldnotes and video recordings. After completing the data collection process, the researcher reflected on the final step of the cycle, whether the integration of $4 \mathrm{C}$ elements (collaboration, communication, creativity, and critical thinking) in the interventions could improve students' English writing skill. In order to determine the effectiveness of peer guidance to help weaker students to improve their English writing skills, the researcher conducted semi-structured interviews with $3 \mathrm{~K}$ class students after they completed the post-test. In addition, the researcher also reflected on the strengths and weaknesses identified in the study and presented suggestions for improvement to overcome the weaknesses.

\subsection{Intervention Procedures}

Based on Table 3, the researcher planned and conducted two sets of interventions (Appendix A \& B) to improve 3K class students English writing skills:

Table 3. Interventions' activities based on the $4 \mathrm{C}$ elements in 21 st-century learning

\begin{tabular}{cl}
\hline Intervention & \multicolumn{1}{c}{ Activity } \\
\hline First set & $\begin{array}{l}\text { In each group, the students held discussions to list out keywords related to } \\
\text { the title "My Family". }\end{array}$ \\
\hline Second set & $\begin{array}{l}\text { In each group, students thought critically and exchanged creative ideas with } \\
\text { each other to write simple sentences related to the title "My Family". }\end{array}$ \\
\hline
\end{tabular}

The planned interventions were divided into two sets. In the first set of intervention (Appendix A), the researcher gave each group of students five minutes to think about the topic "My Family". Next, the students exchanged ideas about the topic and held discussions to list out keywords that are relevant to the topic. During the second set of intervention (Appendix B), the researcher raised a few questions to the students, allowing them to find out the answers for the questions to develop creative and critical thinking. This is so that they can begin writing simple sentences based on the ideas generated from the questions provided.

The planned interventions were different from traditional reinforcement exercises because the students worked in groups during the interventions, where they will have the opportunities to exchange ideas with other group members. In addition, students were guided by questions that allowed them to think critically in order to come up with creative writing ideas in the second set of interventions. Besides that, group-based interventions provided chances for the more accomplished students to guide the weaker students to master English writing skills, especially in the aspects of capitalization, grammar, spelling, and punctuation. Undoubtedly, students preferred to raise questions to their peers as they may be too shy or reluctant to raise their hands and ask questions to the teachers.

In general, the interventions were organized from simple to more challenging levels, where students worked together with group members to list out keywords based on the title given in the group related to the topic given. In this context, the weaker students may be less likely to list keywords related to the topic on their own, but with the guidance of their more competent peers, they were able to list at least one keyword. After listing the keywords, the students were guided to build simple sentences based on the questions provided. Obviously, the questions provided were intended to guide students to think from different perspectives to generate writing ideas. In conclusion, the planned interventions aimed to improve the English writing skills of $3 \mathrm{~K}$ class students.

\subsection{Data Collection Method \& Research Instruments}

The research instruments used by the researcher to collect research data were pre-test and post-test, observation, and semi-structured interview. Undoubtedly, the research instruments selected should be corresponding to the data one wishes to collect based on the objectives stated.

\subsubsection{Pre-test and Post-test}

The researcher prepared 32 sets of test papers (Appendix C) to be given to $3 \mathrm{~K}$ class students during pre-test and post-test, which were before and after the interventions. The purpose of the pre-test and post-test were to see if the writing skill involving aspects of capitalization, grammar, spelling, and punctuation among $3 \mathrm{~K}$ class students were improved after the interventions. The items and questions in the pre-test and post-test were the same, where students built four sentences based on the title: "My School". The rubric (Appendix D) was prepared to ensure that the marks given were fair and not biased. 


\subsubsection{Observation}

The researcher conducted observations on eight groups of $3 \mathrm{~K}$ class students when two sets of interventions took place in the classroom using video recordings and fieldnotes. The observations were conducted to identify the mastery of English writing skills with correct usage of capitalization, grammar, spelling, and punctuation among 3K class students. In addition, the study also aimed to see the involvement of competent and weak students in group activities during both interventions. In this context, the following aspects that have been observed by the researcher are summarized in the following table:

Table 4. Aspects that were observed during observations

\begin{tabular}{cl}
\hline No. & \multicolumn{1}{c}{ Aspect } \\
\hline $\mathbf{1}$ & Students were able to write at least a keyword in their group. \\
\hline $\mathbf{2}$ & Students were able to construct at least a sentence in their group. \\
\hline $\mathbf{3}$ & Students were able to construct sentences with correct punctuation. \\
\hline $\mathbf{4}$ & Students were able to construct sentences with correct spelling. \\
\hline $\mathbf{5}$ & Students were able to construct sentences with correct capitalization. \\
\hline $\mathbf{6}$ & Students were able to construct sentences with correct grammar. \\
\hline
\end{tabular}

\subsubsection{Semi-structured Interview}

The researcher conducted semi-structured interview sessions with the $3 \mathrm{~K}$ class students in their respective groups during recess in the $3 \mathrm{~K}$ class to identify the effectiveness of the $4 \mathrm{C}$ elements-based interventions to improve the writing skills among students involving the aspects of capitalization, grammar, spelling and punctuation and also the students' ability to generate writing ideas. The results of semi-structured interviews were recorded with the smartphone and jotted down in fieldnotes. The questions raised in the interviews are as follows:

Table 5. Semi-structured interview questions

\begin{tabular}{cl}
\hline No. & \multicolumn{1}{c}{ Question } \\
\hline $\mathbf{1}$ & Were you able to generate writing ideas smoothly after the interventions? \\
\hline $\mathbf{2}$ & Were you able to construct sentences with correct punctuation after the interventions? \\
\hline $\mathbf{3}$ & Were you able to construct sentences with correct spelling after the interventions? \\
\hline $\mathbf{4}$ & Were you able to construct sentences with correct capitalization after the interventions? \\
\hline $\mathbf{5}$ & Were you able to construct sentences with correct grammar after the interventions? \\
\hline
\end{tabular}

\subsection{Data Analysis Method}

Generally, data analysis was performed on the research data collected, including pre-test, post-test observations, and semi-structured interviews. The process of analyzing the data has been discussed in detail to ensure that the data collected would be able to answer the research questions presented.

\subsubsection{Pre-test and Post-test}

Two sets of forms (Appendix E \& F) and rubric (Appendix D) were prepared in advance to record pre-test and post-test results. In this context, the researcher gave a score of 0 (Weak), 1 (Moderate) and 2 (Good) based on the usage of capitalization, spelling, grammar, and punctuation in the four sentences constructed by the students. The scores obtained for each sentence were summed up, where the students' achievements were divided into four categories, which are very poor, poor, medium, and good. The students' achievements were analyzed based on the following scoring scheme:

Table 6. Marking scheme for pre-test and post-test

\begin{tabular}{cc}
\hline Scores $(\boldsymbol{\%})$ & Category \\
\hline $24-32$ & Good \\
\hline $16-23$ & Moderate \\
\hline $8-15$ & Poor \\
$0-7$ & Very Poor
\end{tabular}




\subsubsection{Observations}

Specifically, observations were conducted when the students were participating in two sets of interventions in their respective groups in which non-participant observations were conducted. In this context, the researcher jotted down the observations of eight groups by using eight different pieces of A4 papers. The names of the group members were written on each piece of fieldnote. In this context, each fieldnote was divided into two sections, as follows:

Table 7. Fieldnote format (observation)

Names of group members:

Intervention Notes

First set of intervention

\section{Second set of intervention}

\subsubsection{Semi-structured Interview}

Semi-structured interviews were conducted after the students had completed the post-test. In this context, the researcher recorded the answers of the eight groups' students in eight different pieces of A4 papers. Names of the group members were written on each piece of fieldnote. In this context, each fieldnote was divided into five sections, as follows:

Table 8. Fieldnote format (semi-structured interview)

\begin{tabular}{ll}
\hline Names of group members: \\
\hline Interview Question \\
\hline First question \\
\hline Second question \\
\hline Third question \\
\hline Fourth question \\
\hline Fifth question \\
\hline
\end{tabular}

\section{Results}

The findings of the study were collected through pre-test, post-test, observations, and semi-structured interviews based on the two objectives of the study. The study was conducted in $3 \mathrm{~K}$ class involving 16 male students and 16 female students. Eleven students (34.38\%) obtained Grade A (Good), five students (15.62\%) obtained Grade B (Moderate), and sixteen students (50\%) obtained Grade C (Poor) in last year's examination (Year 2018) for English writing.

\subsection{Integrating the Elements of $4 C$ in the Interventions to Improve Students' English Writing Skill}

\subsubsection{Pre-test \& Post-test}

The findings from the pre-test, post-test and observations have shown that the ability to write simple English sentences among $3 \mathrm{~K}$ class students improved after participating in two sets of interventions that were integrated with the elements of collaboration, communication, creativity, and critical thinking. The pre-test was conducted before the students participated in interventions while the post-test was conducted after the students participated in interventions.

The result of the pre-test showed that sixteen of $3 \mathrm{~K}$ class students (50\%) had poor English writing skill. Nine of the 3K class students (28.13\%) had moderate writing skill, while seven students $(21.88 \%)$ had good writing skill. Students' achievement in the pre-test were analyzed based on the usage of capitalization, spelling, grammar, and punctuation in four sentences that they built in the pre-test. Based on Figure 3, it was found that total score obtained by $3 \mathrm{~K}$ class students for spelling was 136 (mean $=4.25$ ) and the total score obtained by $3 \mathrm{~K}$ class students for grammar was 127 $($ mean $=3.97)$. The total score obtained for capitalization was $184($ mean $=5.75)$, while the total score obtained for punctuation was 172 (mean $=5.38)$. The scores obtained by students for spelling and grammar were significantly lower compared to capitalization and punctuation. 


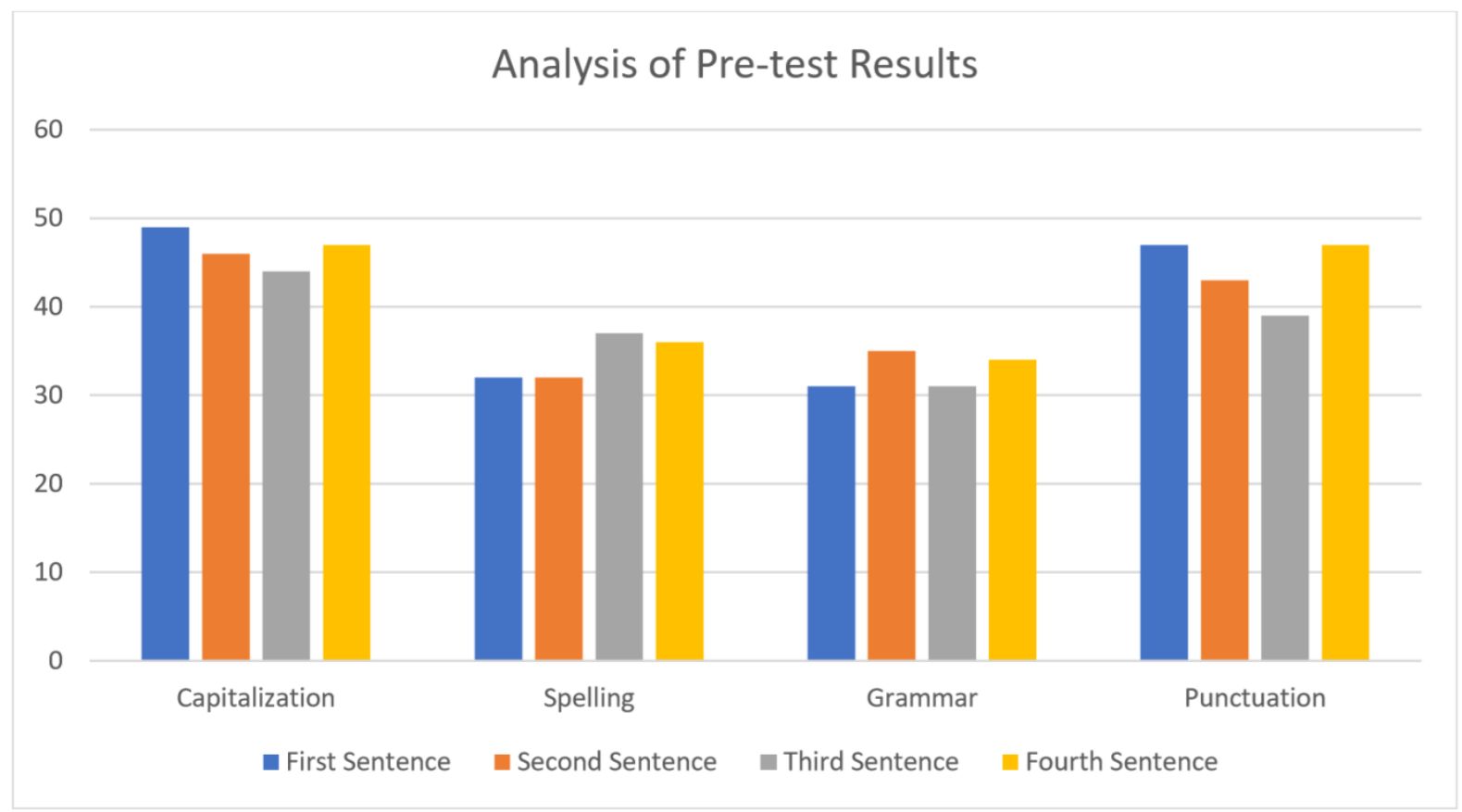

Figure 3. Analysis of pre-test results

The post-test results showed that thirteen of 3K class students (40.63\%) had good writing skills, seventeen of $3 \mathrm{~K}$ class students $(53.13 \%)$ had moderate writing skills, while two students $(6.25 \%)$ had poor writing skills. The student's results were analyzed based on the usage of capitalization, spelling, grammar, and punctuation in the four sentences that they constructed in the post-test. Based on Figure 4, the total score obtained by the 3K class students for the spelling was 152 $($ mean $=4.75)$, and the total score obtained for grammar was 153 (mean $=4.78)$. The total score obtained for capitalization was 216 (mean $=6.75)$, while the total score obtained for punctuation was 204 (mean $=6.38)$. As a result, the $3 \mathrm{~K}$ class students received the highest score for capitalization, while the lowest score was obtained for spelling.

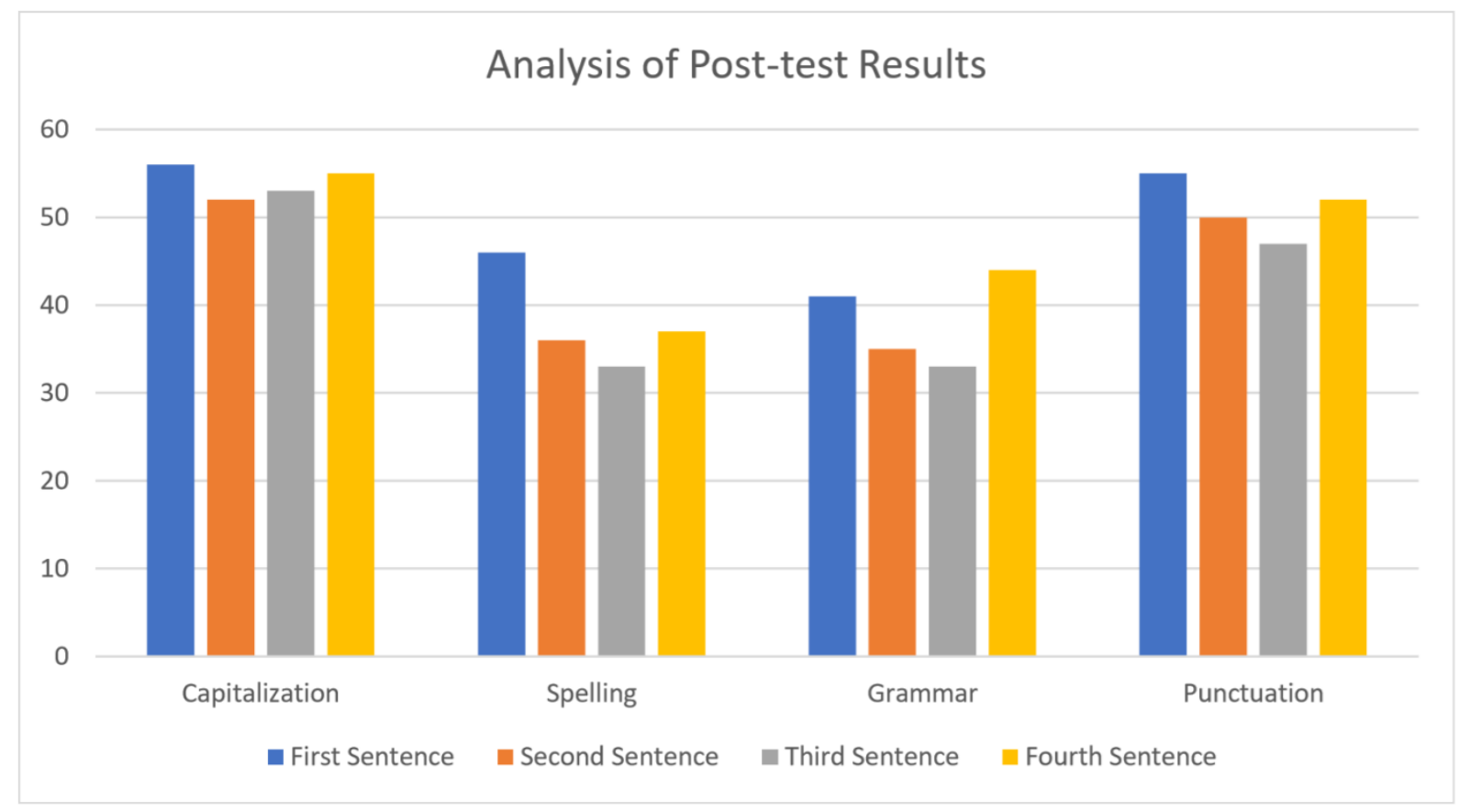

Figure 4. Analysis of post-test results 
A comparison of the pre-test and post-test results was conducted to compare the $3 \mathrm{~K}$ class students' achievements before and after participating in the two sets of interventions. Based on Figure 5, it can be concluded that the students' level of writing, which includes capitalization, spelling, grammar, and punctuation aspects have improved, where the mean score for pre-test is 19.34, while the mean score for the post-test was 22.66 .

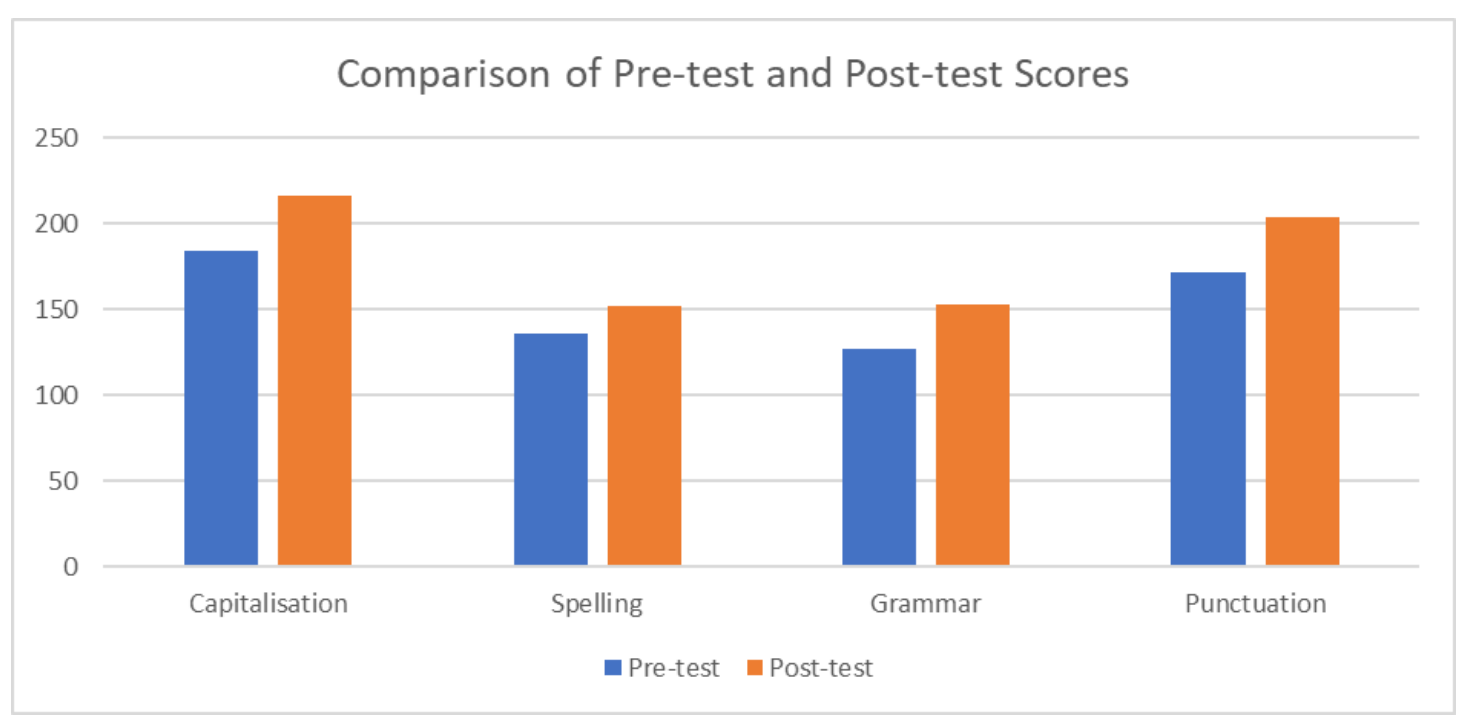

Figure 5. Comparison of pre-test and post-test scores

\subsubsection{Observations}

Observations were made by the researcher when the students were participating in the first and second set of interventions. The results of the first intervention indicated that the students were delighted and showed high levels of interest when they were being informed that interventions will be conducted in groups of four. During the interventions, it was observed that the students who possessed better writing skills in the group asked questions that guided weaker members of the group to think critically and creatively in order to list out the keywords based on the topic given, which is "My Family".

The researcher also discovered that an introvert student who rarely joins any discussions in the class was answering a question asked by his group member. One of the students in the seventh group was seen explaining the correct spelling of the word "patient" to the other group members. The researcher has found that the weak students that have been divided into different groups raised questions regarding the spelling of certain words to their group members. At the end of the first set of intervention, each group was able to list at least five keywords based on the topic given.

The results of the second set of intervention showed that the students manage to build sentences smoothly based on the keywords listed in the first intervention. The students held discussions and exchanged ideas with each other in groups to generate writing ideas. This researcher also discovered that more students who possess better writing skills had raised questions that guided other group members to think creatively to build simple sentences. These students also helped their weaker friends to correct their spellings and grammar mistakes. Meanwhile, the weak students also helped to check the sentences built by the group members, so that no careless mistakes, such as not using a capital letter for the first letter of the sentence and not placing a full stop at the end of the sentence, were made.

\subsection{Identifying the Effectiveness of Peer Guidance in Helping Students to Improve Their English Writing Skill}

\subsubsection{Semi-structured Interviews}

Semi-structured interviews were conducted with eight groups of students, in which the whole process took eight days. The results of the interviews showed that students who possess better writing skills have been guiding weaker students to generate writing ideas through questions, which included keywords such as who, how, and why. The weak students were guided to relate their life experiences to the topic of writing to generate writing ideas. Interactions and discussions between group members also enabled students to build sentences smoothly. The keywords listed in the first set of intervention helped the weak students to build sentences from simple (simple sentence) to difficult (complex sentence).

In terms of capitalization and punctuation, the student stated that they often made careless mistakes, such as not using a capital letter for the first letter of the sentence and not placing a full stop at the end of the sentence. After being reprimanded a few times by their friends and receiving explanations on why it is necessary to use capital letters and 
punctuation marks, the weak students were able to reduce their mistakes. The students who possess better writing skills also explained the usage of capital letter for proper nouns and commas (,) to the weak students, so that they can fully understand the usage of capital letters and different punctuation marks. The weak students claimed that they understood their peers' explanations as the explanations were given gradually.

Besides that, the weak students claimed that they had mastered the correct spellings for some difficult words such as "pepperoni" and "experiment" under the guidance of their peers who possess better writing skills. In addition, the weak students also stated that they managed to master English grammar, such as simple present tense, present continuous tense, and simple past tense. The students claimed that they preferred to engage in writing activities in groups because they could ask their classmates to repeat the explanations until they understand a specific aspect completely.

\section{Discussion}

\subsection{Integrating the Elements of $4 C$ in the Interventions to Improve Students' English Writing Skill}

The results collected from the pre-test and post-tests clearly showed an improvement in the mastery of writing skills among the students of class $3 \mathrm{~K}$. Additionally, observations have demonstrated that the students were actively involved in the interventions that were conducted. In a study by Chiriac (2014), group activities were found to increase interest among students to participate in a learning session and subsequently improve their knowledge in that relevant field.

The students' mastery of capitalization, spelling, grammar, and punctuation increased significantly after participating in the interventions. According to a study by Schweiter (2010), writing skills in the English language can be improved using the scaffolding technique, where more accomplished students guide their weaker peers in grasping important aspects of writing. In this situation, weaker students can request their more accomplished peers to repeat an explanation until they genuinely comprehend specific aspects of capitalization, spelling, grammar, and punctuation.

Clearly, the weaker students scored the lowest marks for grammar in the pre-test. However, their mastery of grammar increased after participating in the interventions. According to a study by Tuan and Doan (2010), the quality of writing can be improved through collaborative writing activities because group members will help to correct grammar mistakes in constructed sentences. In this situation, the more accomplished students and the weaker students will help each other check their sentences to reduce grammatical errors that should not occur.

Observations also demonstrated that students were able to generate writing ideas more smoothly after participating in interventions in groups because they were mentored by their competent peers to think critically and creatively through inquiries with keywords like who, how, and why. This observation has been explained in a study conducted by Fung and Howe (2012). This study discovered that group activities improved critical thinking skills, which are essential to forming ideas while writing in English. Thus, group activities encourage students to think critically through discussions with their peers who have different styles of thinking (Tully, 2009).

\subsection{Identify the Effectiveness of Peer Guidance in Helping Students to Improve Their English Writing Skill}

The results of the semi-structured interviews showed that weaker students agree that the guidance of more competent peers helped them to develop writing ideas and increase their mastery over aspects of capitalization, spelling, grammar, and punctuation. According to a study conducted by Pyle et al. (2017), peer guidance can improve vocabulary mastery and student's comprehension in English more if compared to teacher-centered teaching and learning activities.

The students also claimed that their more competent peers guided them gradually to think critically and creatively to generate keywords related to the topic of writing. According to Bean (2011), the process of listing keywords helps students to get a more comprehensive idea of what content they wish to present in their writing. In addition, the weak students claimed that their more competent peers often remind them of the correct usage of capitalization, spelling, grammar, and punctuation. According to a study conducted by Yang Yu-Fen (2011), group learning activities enable students to give advice to their peers and correct mistakes made by group members.

One of the students stated that group-based writing exercises allowed them to master and apply capitalization, spelling, grammar, and punctuation correctly as they were given opportunities to have discussions with their peers. Traditional teacher-centered teaching methods often cause students to be passive, whereas student-centered learning process, such as discussions and group-based activities, enable students to remember and master certain aspects (Adas \& Bakir 2013).

Some students felt that peer mentoring in a group was more effective in helping them to master difficult aspects, such as grammar. Indeed, peers play an important role in helping students to master a certain aspect of knowledge, whereby they guide weak students by repeating the content delivered by teachers and providing guidance and feedback to the weak students gradually (Castañeda-Londoño 2017). 


\section{Conclusion}

The $4 \mathrm{C}$ elements of 21st-century learning, namely collaboration, communication, creativity, and critical thinking, play an essential role in the learning process of students. Students are encouraged to collaborate and communicate with friends or teachers in their learning process. Students are also taught to think critically and creatively to master, evaluate and synthesize knowledge that they gained. The study aimed to integrate the $4 \mathrm{C}$ elements in interventions to improve the English writing skills among 3K class students.

The study showed positive impacts for students and teachers, where students were trained to generate writing ideas through critical and creative thinking as well as increase their mastery of the aspects of capitalization, spelling, grammar, and punctuation under peer guidance. Teachers who teach language subjects, especially English, should plan more group teaching and learning activities as student-centered group activities enable students to master a variety of content effectively through active engagement and discussions with group members.

This researcher recommends that further research to be undertaken by modifying existing intervention so that it can be used to enhance student's writing skill in essay form. For example, the students listed four main contents that they wish to present in their short essay during the first intervention through group discussion and then, writing a complete essay by using the correct capitalization, spelling, grammar, and punctuation in the second set of intervention. Thus, students' English writing skills can be improved.

\section{References}

Adas, D., \& Bakir, A. (2013). Writing difficulties and new solutions: Blended learning as an approach to improve writing abilities. International Journal of Humanities and Social Science, 3(9), 254-266.

Aminuddin Baki Institution. (2017). Handbook of 21st Century Learning Implementation. Negeri Sembilan: Aminuddin Baki Institution.

Azizah, A. H. (2009). Mastery and usage of English language among PKPG students in University of Technology Malaysia. (Master's thesis). University of Technology Malaysia, Skudai, Johor.

Bean, J. C. (2011). Engaging Ideas: The Professor's Guide to Integrating Writing, Critical Thinking and Active Learning in the Classroom. San Francisco: John Wiley \& Sons, Incorporated.

Beetham, H., \& Sharpe, R. (2013). Rethinking Pedagogy for a Digital Age: Designing for 21 st Century Learning. New York: Routledge.

Castañeda-Londoño, A. C. (2017). Exploring English teachers' perceptions about peer-coaching as a professional development activity of knowledge construction. HOW, 24(2), 80-101. https://doi.org/10.19183/how.24.2.345

Chiriac, E. H. (2014). Group work as an incentive for learning - students' experiences of group work. Frontiers in Psychology, 5(558), 1-10. https://doi.org/10.3389/fpsyg.2014.00558

Elola, I., \& Oskoz, A. (2010). Collaborative writing: Fostering foreign language and writing conventions development. Language Learning and Technology, 14(3), 51-71.

Fung, D., \& Howe, C. (2012). Liberal studies in Hong Kong: A new perspective on critical thinking through group work. Thinking Skills and Creativity, 7(2), 101-111. https://doi.org/10.1016/j.tsc.2012.04.002

Ghabool, N., Mariadass, M. E., \& Kashef, S. H. (2012). Investigating Malaysian ESL students' writing problems on conventions, punctuation, and language use at secondary school level. Journal of Studies in Education, 2(3), 130-143. https://doi.org/10.5296/jse.v2i3.1892

Harland, T. (2003). Vygotsky's Zone of Proximal Development and Problem-based Learning: Linking a theoretical concept with practice through action research. Teaching in Higher Education, 8(2), 263-272. https://doi.org/10.1080/1356251032000052483

Jones, L. (2007). The Student-Centred Classroom. Cambridge: Cambridge University Press.

Larson, M. G. (2006). Descriptive statistics and graphical displays. Circulation, 114(1), 76-81. https://doi.org/10.1161/CIRCULATIONAHA.105.584474

Levykh, M. G. (2008). The affective establishment and maintenance of Vygotsky's zone of proximal development. Educational Theory, 58(1), 83-101. https://doi.org/10.1111/j.1741-5446.2007.00277.x

Lewin, K. (1946). Action research and minority problems. Journal of Social Issues, 2(4), 34-36. https://doi.org/10.1111/j.1540-4560.1946.tb02295.x 
Lim, T. D. (2013). Analyzing Malaysian English classrooms: reading, writing, speaking and listening teaching strategies (Master's thesis). University of Washington, Washington, United States of America. https://digital.lib.washington.edu/researchworks/handle/1773/25020

Lin, Y. S. (2011). Fostering creativity through education- A conceptual framework of creative pedagogy. Creative Education, 2(3), 149-155. https://doi.org/10.4236/ce.2011.23021

Lourenco, F., \& Jones, O. (2006). Developing entrepreneurship education: Comparing traditional and alternative teaching approaches. International Journal of Entrepreneurship Education, 4, 111-140.

Maros, M., Tan, K. H., \& Khazriyati, S. (2007). Interference in learning English: Grammatical errors in English essay writing among rural Malay secondary school students in Malaysia. Electronic Journal of Faculty Science Social and Humanity of National University of Malaysia, 2(2), 1-15. http://journalarticle.ukm.my/1539/

Nauman, A. D., Stirling, T., \& Borthwick, A. (2011). What makes writing good? An essential question for teachers. The Reading Teacher, 64(5), 318-328. https://doi.org/10.1598/RT.64.5.2

Pyle, D., Pyle, N., Lignugaris, K. B., Duran, L., \& Akers, J. (2017). Academic effects of peer-mediated interventions with english language learners: A research synthesis. Review of Educational Research, 87(1), 103-133. https://doi.org/10.3102/0034654316653663

Rethinasamy, S., \& Chuah, K. M. (2011). The Malaysian University English Test (MUET) and its use for placement purposes: A predictive validity study. Electronic Journal of Foreign Language Teaching, 8(2), 234-245. https://doi.org/10.2139/ssrn.2146007

Roberts, P. (2009). Paulo Freire in the 21st Century: Education, Dialogue, and Transformation. New York: Routledge.

Sala, M. P., \& Redford, P. (2012). Writing essays: does self-efficacy matter? The relationship between self-efficacy in reading and in writing and undergraduate students' performance in essay writing. Journal of Educational Psychology, 32(1), 9-20. https://doi.org/10.1080/01443410.2011.621411

Schwieter, J. W. (2010). Developing second language writing through scaffolding in the ZPD: A magazine project for an authentic audience. Journal of College Teaching \& Learning, 7(10), 31-46. https://doi.org/10.19030/tlc.v7i10.154

Shabani, K., Khatib, M., \& Ebadi, S. (2010). Vygotsky's Zone of Proximal Development: Instructional implications and teachers' professional development. English Language Teaching, 3(4), 237-248. https://doi.org/10.5539/elt.v3n4p237

Shaik, R. A. (2016). Importance of English communication skills. International Journal of Applied Research, 2(3), 478-480. http://www.allresearchjournal.com/archives/2016/vol2issue3/PartH/2-3-47.pdf

Tuan, L. T., \& Doan, N. T. M. (2010). Teaching english grammar through games. Studies in Literature and Language, I(7), 61-75. http://cscanada.net/index.php/sll/article/download/j.sll.1923156320100107.006/1463

Tully, M. M. (2009). Mind mirror projects: A tool for integrating critical thinking into the English language classroom. English Teaching Forum, 47(1), 10-17. http://exchanges.state.gov/englishteaching/forum/archives/docs/09-47-1-c.pdf

Wang, T. P. (2007). The comparison of the difficulties between cooperative learning and traditional teaching methods in college English teachers. The Journal of Human Resource and Adult Learning, 3(2), 23-30. http://www.hraljournal.com/Page/4\%20Tzu-Pu\%20Wang.pdf

Yang, Y. F. (2011). A reciprocal peer review system to support college students' writing. British Journal of Educational Technology, 42(4), 687-700. https://doi.org/10.1111/j.1467-8535.2010.01059.x 


\section{Appendix A}

\section{First Set of Intervention}

Guidelines for the teacher:

- Before starting to explain, makes sure that each group consists of four students.

- Distribute exercise papers for each group.

- Explain the title given - "My Family"

- Let students start their discussions in group and list out keywords related to their family in the space provided.

Instruction: Write down keywords related to your family.

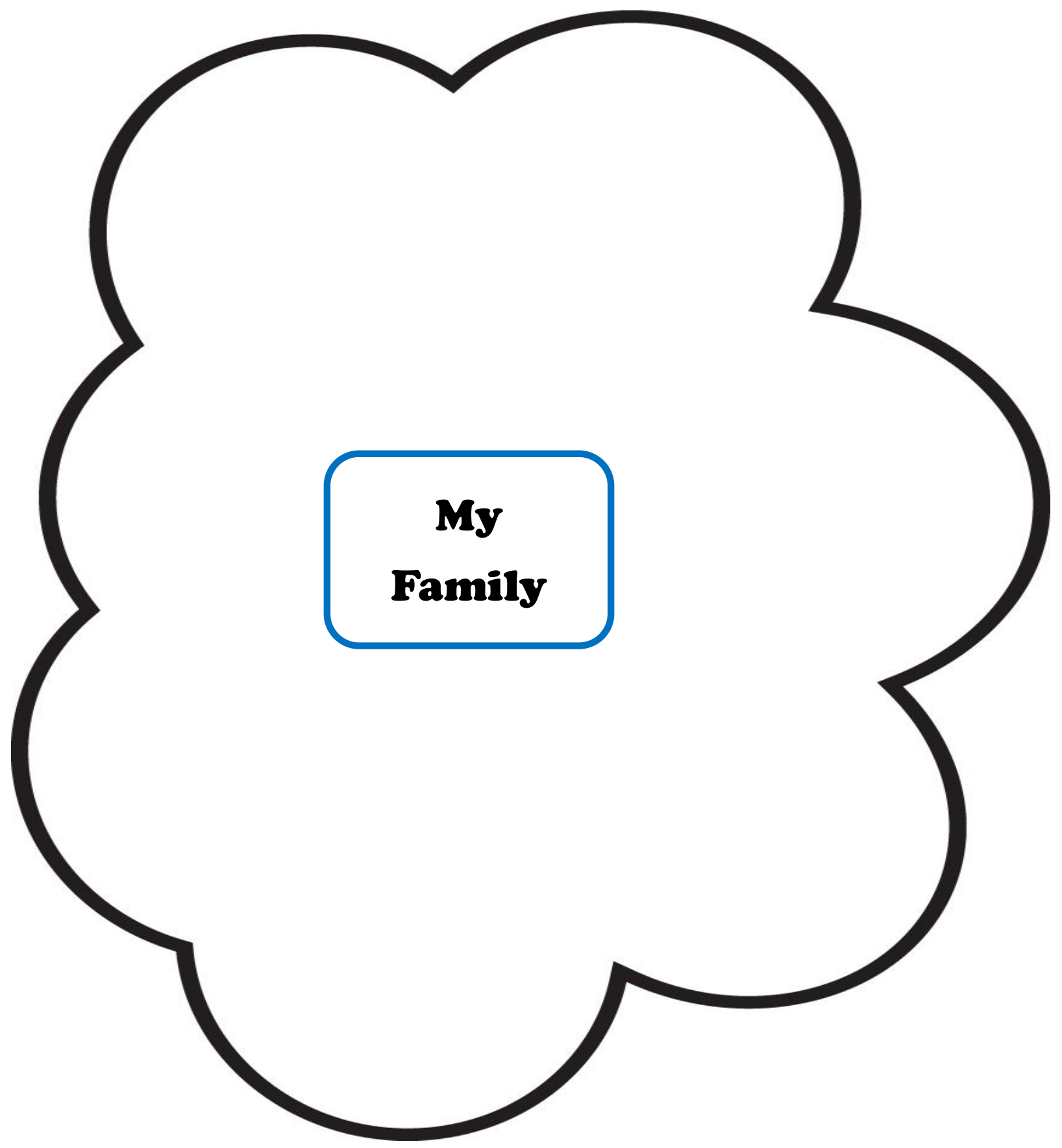




\section{Appendix B}

\section{$\underline{\text { Second Set of Intervention }}$}

Asking questions to develop ideas:

- Who is in your family?

- Do you wish to have a sister or brother? Why?

- Who do you love the most in your family? How do you express your love?

- Would you introduce your family members to your friends?

- Anything else you want to share with us about your family?

\section{Instruction: Write your sentences in the boxes.}
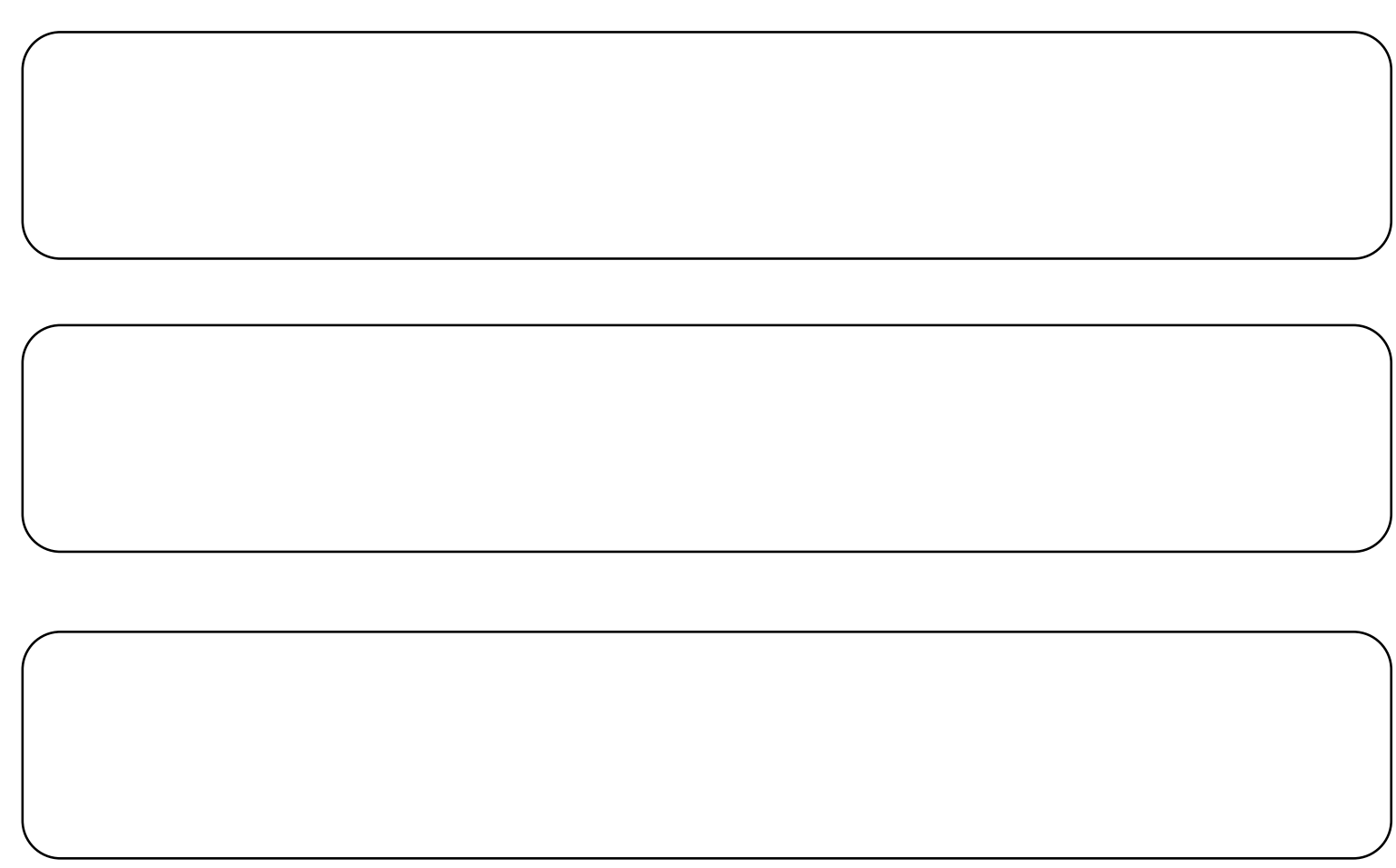


\section{Appendix C}

\section{Pre-test/ Post-test}

Topic: My School

NAME:

CLASS:

*Instruction: Write your sentences in the boxes.

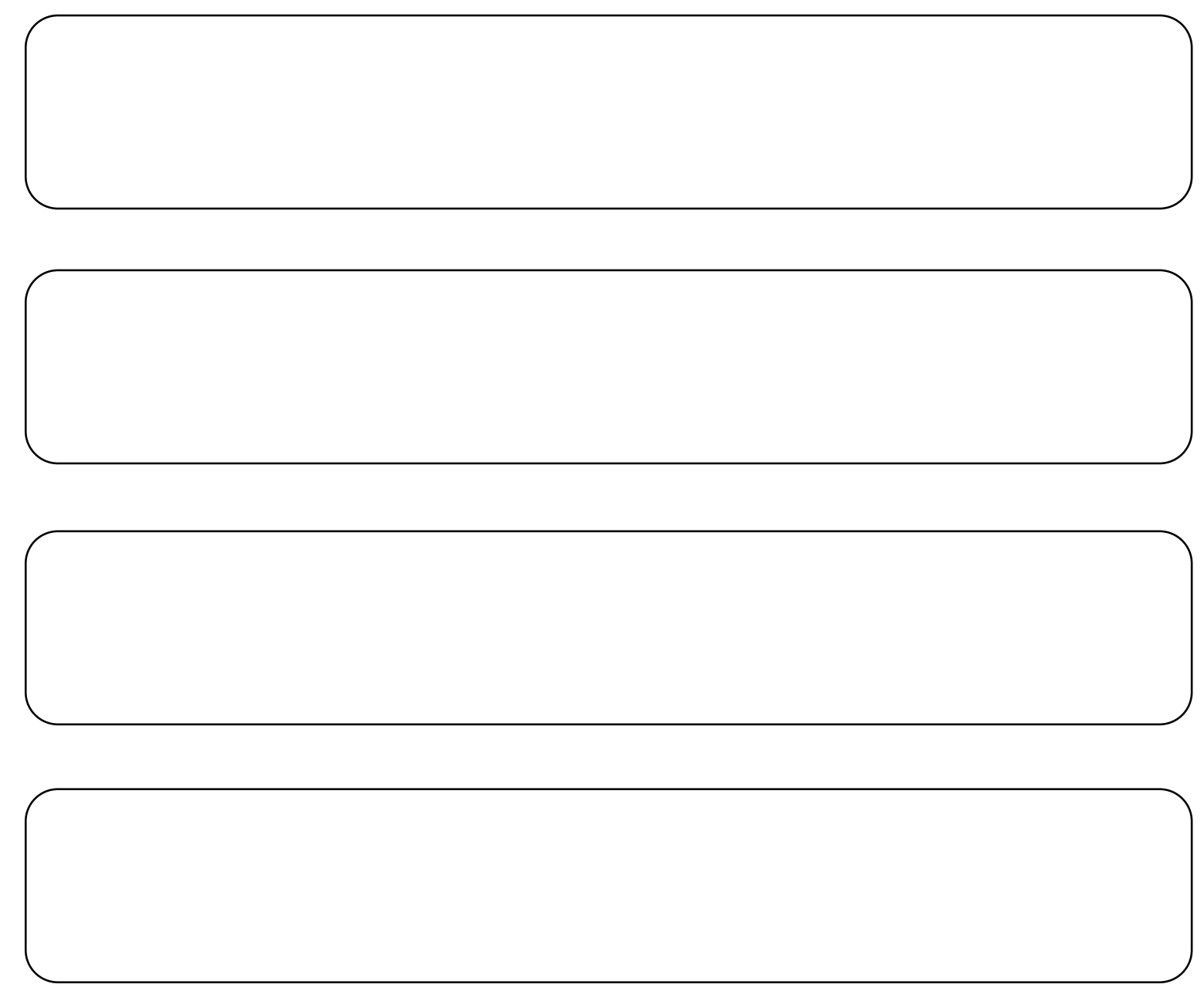




\section{Appendix D}

\section{Rubric for Pre-test \& Post-test}

\begin{tabular}{|c|c|c|c|}
\hline \multirow{2}{*}{ Criteria } & \multicolumn{3}{|c|}{ Points } \\
\hline & 0 & 1 & 2 \\
\hline Spelling & $\begin{array}{l}\text { The sentence contains } \\
\text { more than } 2 \text { misspelled } \\
\text { words. }\end{array}$ & $\begin{array}{l}\text { The sentence contains 1-2 } \\
\text { misspelled words. }\end{array}$ & $\begin{array}{l}\text { All words are spelled } \\
\text { correctly. }\end{array}$ \\
\hline Capitalization & $\begin{array}{l}\text { The sentence has more } \\
\text { than } 2 \text { errors in } \\
\text { capitalization. }\end{array}$ & $\begin{array}{c}\text { The sentence has } 1 \text { or } 2 \text { error } \\
\text { in capitalization. }\end{array}$ & $\begin{array}{c}\text { The sentence begins with } \\
\text { a capital letter and has no } \\
\text { capitalization errors. }\end{array}$ \\
\hline Grammar & $\begin{array}{l}\text { The sentence has more } \\
\text { than } 2 \text { grammatical errors, } \\
\text { and the sentence is } \\
\text { incomprehensible. }\end{array}$ & $\begin{array}{l}\text { The sentence has 1-2 } \\
\text { grammatical errors, but the } \\
\text { sentence is comprehensible. }\end{array}$ & $\begin{array}{l}\text { The sentence is } \\
\text { grammatically correct } \\
\text { with no structural errors. }\end{array}$ \\
\hline Punctuation & $\begin{array}{l}\text { The sentence does not } \\
\text { contain the correct ending } \\
\text { punctuation. There are } \\
\text { more than } 2 \text { errors in } \\
\text { commas and other } \\
\text { punctuation marks. }\end{array}$ & $\begin{array}{l}\text { The sentence contains the } \\
\text { correct ending punctuation. } \\
\text { There are 1-2 errors in } \\
\text { commas and other } \\
\text { punctuation marks. }\end{array}$ & $\begin{array}{l}\text { The sentence contains the } \\
\text { correct ending } \\
\text { punctuation. Commas } \\
\text { and other punctuation } \\
\text { marks are used correctly. }\end{array}$ \\
\hline
\end{tabular}




\section{Appendix E}

\section{Pre-test Results}

\begin{tabular}{|c|c|c|c|c|c|c|c|c|c|c|c|c|c|c|c|c|c|c|}
\hline \multirow[t]{2}{*}{ No. } & \multirow[t]{2}{*}{ Students } & \multicolumn{4}{|c|}{$\begin{array}{c}\text { Spelling } \\
\text { (2P) }\end{array}$} & \multicolumn{4}{|c|}{$\begin{array}{c}\text { Capitalization } \\
(2 \mathrm{P})\end{array}$} & \multicolumn{4}{|c|}{$\begin{array}{c}\text { Grammar } \\
(2 P)\end{array}$} & \multicolumn{4}{|c|}{$\begin{array}{c}\text { Punctuation } \\
\text { (2P) }\end{array}$} & \multirow[t]{2}{*}{$\begin{array}{r}\text { Total } \\
\text { Point } \\
\end{array}$} \\
\hline & & 1 & 2 & 3 & 4 & 1 & 2 & 3 & 4 & 1 & 2 & 3 & 4 & 1 & 2 & 3 & 4 & \\
\hline 1 & S1 & 0 & 0 & 1 & 2 & 1 & 1 & 1 & 2 & 1 & 0 & 0 & 1 & 2 & 1 & 1 & 1 & 15 \\
\hline 2 & S2 & 2 & 1 & 1 & 2 & 2 & 2 & 2 & 2 & 1 & 2 & 1 & 1 & 1 & 2 & 2 & 1 & 25 \\
\hline 3 & S3 & 0 & 1 & 0 & 1 & 2 & 1 & 1 & 1 & 0 & 1 & 1 & 0 & 2 & 1 & 2 & 1 & 15 \\
\hline 4 & S4 & 0 & 2 & 2 & 2 & 1 & 2 & 2 & 1 & 2 & 1 & 2 & 1 & 2 & 2 & 1 & 1 & 24 \\
\hline 5 & S5 & 1 & 2 & 1 & 2 & 2 & 1 & 2 & 2 & 1 & 1 & 2 & 2 & 1 & 2 & 2 & 2 & 26 \\
\hline 6 & S6 & 0 & 2 & 1 & 1 & 2 & 2 & 1 & 2 & 1 & 2 & 2 & 1 & 2 & 1 & 2 & 1 & 23 \\
\hline 7 & S7 & 2 & 2 & 2 & 0 & 1 & 2 & 1 & 2 & 2 & 1 & 1 & 1 & 2 & 1 & 1 & 2 & 23 \\
\hline 8 & S8 & 1 & 1 & 2 & 2 & 0 & 1 & 2 & 2 & 0 & 1 & 2 & 2 & 1 & 2 & 2 & 1 & 22 \\
\hline 9 & S9 & 2 & 1 & 2 & 1 & 2 & 2 & 1 & 2 & 2 & 2 & 1 & 0 & 0 & 1 & 2 & 2 & 23 \\
\hline 10 & $\mathrm{~S} 10$ & 0 & 1 & 0 & 1 & 1 & 1 & 2 & 2 & 0 & 0 & 1 & 1 & 1 & 1 & 2 & 1 & 15 \\
\hline 11 & S11 & 1 & 0 & 0 & 1 & 2 & 1 & 1 & 1 & 1 & 1 & 0 & 0 & 2 & 1 & 1 & 2 & 15 \\
\hline 12 & $\mathrm{~S} 12$ & 1 & 1 & 2 & 2 & 2 & 2 & 2 & 2 & 1 & 2 & 1 & 2 & 2 & 2 & 1 & 1 & 26 \\
\hline 13 & $\mathrm{~S} 13$ & 0 & 1 & 1 & 0 & 1 & 1 & 2 & 1 & 2 & 2 & 0 & 1 & 1 & 1 & 0 & 1 & 15 \\
\hline 14 & S14 & 0 & 0 & 1 & 1 & 2 & 1 & 1 & 2 & 1 & 0 & 0 & 1 & 2 & 2 & 1 & 0 & 15 \\
\hline 15 & S15 & 2 & 2 & 1 & 0 & 2 & 1 & 1 & 2 & 2 & 1 & 1 & 1 & 1 & 2 & 2 & 2 & 23 \\
\hline 16 & S16 & 1 & 1 & 1 & 1 & 1 & 2 & 0 & 2 & 0 & 0 & 1 & 1 & 1 & 0 & 1 & 1 & 14 \\
\hline 17 & $\mathrm{~S} 17$ & 2 & 1 & 2 & 2 & 2 & 1 & 2 & 1 & 0 & 1 & 2 & 2 & 2 & 1 & 1 & 1 & 23 \\
\hline 18 & $\mathrm{~S} 18$ & 0 & 1 & 2 & 0 & 1 & 2 & 1 & 1 & 1 & 0 & 0 & 1 & 1 & 2 & 1 & 1 & 15 \\
\hline 19 & S19 & 0 & 0 & 0 & 1 & 2 & 1 & 0 & 2 & 1 & 1 & 0 & 0 & 2 & 1 & 0 & 2 & 13 \\
\hline 20 & $\mathrm{~S} 20$ & 1 & 1 & 1 & 0 & 2 & 1 & 1 & 1 & 0 & 1 & 1 & 0 & 1 & 2 & 0 & 1 & 14 \\
\hline 21 & S21 & 0 & 2 & 1 & 0 & 2 & 2 & 1 & 1 & 0 & 0 & 1 & 1 & 0 & 1 & 1 & 2 & 15 \\
\hline 22 & S22 & 2 & 1 & 2 & 2 & 1 & 2 & 2 & 1 & 2 & 2 & 1 & 2 & 2 & 1 & 2 & 2 & 27 \\
\hline 23 & $\mathrm{~S} 23$ & 0 & 0 & 1 & 2 & 2 & 2 & 0 & 1 & 0 & 1 & 1 & 0 & 1 & 2 & 0 & 2 & 15 \\
\hline 24 & S24 & 2 & 1 & 1 & 0 & 2 & 1 & 1 & 0 & 1 & 0 & 0 & 1 & 2 & 0 & 2 & 1 & 15 \\
\hline 25 & S25 & 2 & 2 & 0 & 0 & 1 & 2 & 2 & 0 & 1 & 1 & 0 & 0 & 1 & 0 & 1 & 2 & 15 \\
\hline 26 & S26 & 2 & 1 & 1 & 2 & 2 & 1 & 2 & 1 & 2 & 2 & 2 & 1 & 2 & 2 & 1 & 2 & 26 \\
\hline 27 & S27 & 1 & 1 & 0 & 2 & 2 & 1 & 2 & 2 & 0 & 2 & 1 & 2 & 1 & 2 & 2 & 2 & 23 \\
\hline 28 & S28 & 2 & 1 & 1 & 1 & 0 & 0 & 1 & 1 & 0 & 0 & 1 & 1 & 2 & 1 & 0 & 2 & 14 \\
\hline 29 & S29 & 0 & 0 & 1 & 1 & 1 & 2 & 2 & 0 & 1 & 1 & 0 & 2 & 1 & 2 & 1 & 0 & 15 \\
\hline 30 & S30 & 2 & 1 & 2 & 2 & 1 & 1 & 2 & 2 & 1 & 1 & 2 & 2 & 1 & 0 & 2 & 1 & 23 \\
\hline 31 & S31 & 1 & 0 & 2 & 1 & 2 & 2 & 2 & 2 & 2 & 2 & 1 & 1 & 2 & 2 & 0 & 2 & 30 \\
\hline \multirow[t]{3}{*}{32} & S32 & 2 & 1 & 1 & 1 & 2 & 1 & 1 & 2 & 1 & 2 & 1 & 1 & 2 & 1 & 2 & 2 & 23 \\
\hline & & 32 & 32 & 36 & 36 & 49 & 45 & 44 & 46 & 30 & 34 & 30 & 33 & 46 & 42 & 39 & 45 & \\
\hline & & \multicolumn{4}{|c|}{136} & \multicolumn{4}{|c|}{184} & \multicolumn{4}{|c|}{127} & \multicolumn{4}{|c|}{172} & \\
\hline
\end{tabular}


*Total points for each sentence: 8 points.

* Total points for the test: 32 points.

\begin{tabular}{|c|c|}
\hline Number & Sentence \\
\hline 1 & First sentence \\
\hline 2 & Second sentence \\
\hline 3 & Third sentence \\
\hline 4 & Fourth sentence \\
\hline
\end{tabular}




\section{Appendix F}

\section{Post-test Results}

\begin{tabular}{|c|c|c|c|c|c|c|c|c|c|c|c|c|c|c|c|c|c|c|}
\hline \multirow[t]{2}{*}{ No. } & \multirow[t]{2}{*}{ Students } & \multicolumn{4}{|c|}{$\begin{array}{l}\text { Spelling } \\
\text { (2P) }\end{array}$} & \multicolumn{4}{|c|}{$\begin{array}{c}\text { Capitalization } \\
\text { (2P) }\end{array}$} & \multicolumn{4}{|c|}{$\begin{array}{c}\text { Grammar } \\
\text { (2P) }\end{array}$} & \multicolumn{4}{|c|}{$\begin{array}{l}\text { Punctuation } \\
\text { (2P) }\end{array}$} & \multirow[t]{2}{*}{$\begin{array}{l}\text { Total } \\
\text { Points }\end{array}$} \\
\hline & & $\mathbf{1}$ & 2 & 3 & 4 & 1 & 2 & 3 & 4 & 1 & 2 & 3 & 4 & 1 & 2 & 3 & 4 & \\
\hline 1 & S1 & 1 & 1 & 1 & 0 & 2 & 1 & 2 & 0 & 1 & 0 & 2 & 1 & 1 & 2 & 0 & 2 & 17 \\
\hline 2 & S2 & 2 & 1 & 2 & 2 & 2 & 2 & 2 & 2 & 2 & 1 & 1 & 2 & 2 & 2 & 2 & 2 & 29 \\
\hline 3 & S3 & 1 & 2 & 0 & 2 & 1 & 2 & 2 & 2 & 1 & 2 & 0 & 1 & 2 & 1 & 1 & 2 & 22 \\
\hline 4 & S4 & 2 & 0 & 0 & 1 & 1 & 1 & 1 & 2 & 1 & 1 & 0 & 2 & 1 & 1 & 2 & 1 & 19 \\
\hline 5 & S5 & 2 & 2 & 2 & 2 & 2 & 2 & 2 & 1 & 2 & 2 & 2 & 1 & 2 & 2 & 2 & 2 & 30 \\
\hline 6 & S6 & 2 & 2 & 0 & 2 & 2 & 2 & 2 & 2 & 1 & 2 & 2 & 0 & 2 & 0 & 1 & 2 & 24 \\
\hline 7 & S7 & 1 & 2 & 2 & 2 & 2 & 2 & 2 & 2 & 2 & 0 & 1 & 2 & 1 & 2 & 2 & 2 & 27 \\
\hline 8 & S8 & 2 & 2 & 1 & 2 & 2 & 2 & 1 & 2 & 2 & 1 & 0 & 1 & 2 & 2 & 2 & 2 & 26 \\
\hline 9 & S9 & 1 & 2 & 0 & 2 & 1 & 2 & 2 & 2 & 1 & 2 & 0 & 2 & 2 & 1 & 2 & 2 & 24 \\
\hline 10 & S10 & 1 & 1 & 1 & 0 & 2 & 1 & 2 & 2 & 1 & 1 & 0 & 1 & 2 & 1 & 0 & 2 & 18 \\
\hline 11 & S11 & 0 & 2 & 1 & 2 & 1 & 1 & 2 & 2 & 0 & 2 & 0 & 1 & 2 & 2 & 1 & 2 & 21 \\
\hline 12 & S12 & 1 & 2 & 2 & 2 & 2 & 2 & 2 & 2 & 2 & 1 & 2 & 2 & 2 & 2 & 2 & 2 & 30 \\
\hline 13 & S13 & 2 & 0 & 2 & 1 & 2 & 1 & 2 & 2 & 1 & 1 & 2 & 0 & 2 & 2 & 1 & 1 & 22 \\
\hline 14 & S14 & 2 & 1 & 0 & 1 & 2 & 1 & 2 & 1 & 2 & 2 & 2 & 1 & 2 & 2 & 1 & 1 & 23 \\
\hline 15 & S15 & 2 & 0 & 2 & 1 & 2 & 2 & 2 & 2 & 1 & 2 & 0 & 2 & 2 & 1 & 2 & 2 & 25 \\
\hline 16 & S16 & 1 & 0 & 1 & 0 & 1 & 2 & 1 & 1 & 2 & 0 & 1 & 2 & 2 & 0 & 1 & 2 & 17 \\
\hline 17 & S17 & 2 & 0 & 1 & 0 & 2 & 2 & 2 & 2 & 2 & 0 & 2 & 1 & 2 & 2 & 2 & 2 & 24 \\
\hline 18 & S18 & 1 & 2 & 2 & 1 & 2 & 0 & 1 & 2 & 0 & 1 & 0 & 2 & 1 & 2 & 2 & 2 & 21 \\
\hline 19 & S19 & 0 & 0 & 0 & 1 & 2 & 1 & 0 & 2 & 2 & 0 & 2 & 0 & 2 & 0 & 1 & 2 & 15 \\
\hline 20 & S20 & 2 & 1 & 0 & 0 & 1 & 2 & 1 & 0 & 1 & 2 & 1 & 2 & 0 & 1 & 0 & 1 & 15 \\
\hline 21 & S21 & 2 & 0 & 2 & 0 & 1 & 2 & 2 & 2 & 0 & 1 & 1 & 0 & 0 & 2 & 2 & 1 & 18 \\
\hline 22 & S22 & 2 & 1 & 2 & 2 & 2 & 2 & 2 & 2 & 1 & 2 & 2 & 1 & 2 & 2 & 2 & 2 & 29 \\
\hline 23 & S23 & 0 & 2 & 0 & 2 & 2 & 2 & 1 & 2 & 2 & 0 & 1 & 1 & 2 & 2 & 2 & 1 & 22 \\
\hline 24 & S24 & 0 & 2 & 1 & 0 & 2 & 2 & 2 & 1 & 2 & 0 & 1 & 1 & 2 & 1 & 2 & 0 & 19 \\
\hline 25 & S25 & 2 & 0 & 0 & 1 & 2 & 1 & 2 & 2 & 0 & 1 & 0 & 2 & 1 & 2 & 1 & 0 & 17 \\
\hline 26 & S26 & 1 & 2 & 2 & 2 & 2 & 2 & 2 & 2 & 1 & 1 & 2 & 2 & 2 & 2 & 2 & 2 & 29 \\
\hline 27 & S27 & 2 & 0 & 1 & 1 & 2 & 2 & 2 & 2 & 1 & 0 & 1 & 2 & 2 & 1 & 2 & 2 & 23 \\
\hline 28 & S28 & 2 & 1 & 0 & 0 & 1 & 2 & 2 & 2 & 0 & 2 & 1 & 1 & 2 & 2 & 1 & 2 & 21 \\
\hline 29 & S29 & 2 & 2 & 2 & 1 & 2 & 2 & 1 & 2 & 2 & 1 & 2 & 2 & 2 & 2 & 2 & 2 & 10 \\
\hline 30 & S30 & 2 & 0 & 1 & 0 & 2 & 2 & 0 & 2 & 2 & 1 & 0 & 2 & 2 & 2 & 1 & 0 & 19 \\
\hline 31 & S31 & 1 & 2 & 2 & 2 & 2 & 2 & 2 & 1 & 1 & 2 & 2 & 2 & 2 & 2 & 2 & 2 & 29 \\
\hline \multirow[t]{3}{*}{32} & S32 & 2 & 1 & 0 & 2 & 2 & 0 & 2 & 2 & 2 & 1 & 0 & 2 & 2 & 2 & 1 & 2 & 23 \\
\hline & & 46 & 36 & 33 & 37 & 56 & 52 & 53 & 55 & 41 & 35 & 33 & 44 & 55 & 50 & 47 & 52 & \\
\hline & & \multicolumn{4}{|c|}{152} & \multicolumn{4}{|c|}{216} & \multicolumn{4}{|c|}{153} & \multicolumn{4}{|c|}{204} & \\
\hline
\end{tabular}


*Total points for each sentence: 8 points.

* Total points for the test: 32 points.

\begin{tabular}{|c|c|}
\hline Number & Sentence \\
\hline 1 & First sentence \\
\hline 2 & Second sentence \\
\hline 3 & Third sentence \\
\hline 4 & Fourth sentence \\
\hline
\end{tabular}

\section{Copyrights}

Copyright for this article is retained by the author(s), with first publication rights granted to the journal.

This is an open-access article distributed under the terms and conditions of the Creative Commons Attribution license which permits unrestricted use, distribution, and reproduction in any medium, provided the original work is properly cited. 